\title{
RECOGNITION OF ILLEGITIMATE CHILDREN \\ IN VARIOUS LAWS IN INDONESIA
}

\author{
Yunanto \\ Faculty of Law, Diponegoro University, Semarang \\ yun_yunanto@yahoo.com
}

\begin{abstract}
In any regulations in Indonesia, there are differences in the inherent status and rights between legitimate and illegitimate children. Consequently, it surely affects the relationship between the children and their parents. Illegitimate children only have the civil relationship with their mothers. In order that the illegitimate children have a certain relationship with their biological fathers, it requires a legal action in the form of the recognition of biological father. However, there are legal ambiguities in the regulations that govern the institution of the recognition of children as stated in the Indonesian Civil Code, Law No. 23 of 2006 in conjunction with Law No. 24 of 2013, and the Decisions of the Constitutional Court No. 46/ PUU-VIII/ 2010 as a corrective provision to the Marriage Law (UUP), and the Islamic Law Compilation (KHI). The legal effects are: the discrimination derived from legal injustice and certainty in the implementation of the child recognition.
\end{abstract}

Keywords: recognition, Illegitimate Children, various laws.

\section{Introduction}

Birth is a legal event that raises a lot of legal effects because it will create the relationships of inheritance, family, trust, and others associated with the appearance of new legal subjects to the world with all their status and positions before law. ${ }^{1}$ Thus, the presence of a child plays an important role in family life.

A child, regardless born from anyone and any cause, should receive legal protection. The reality is that, by the laws, children are discriminated in their position and rights that accompany them. The disparities apply between legitimate

${ }^{1}$ D.Y. Witanto, Hukum Keluarga : Hak dan Kedudukan Anak Luar Kawin (Family Law: The Rights and Position of Illegitimate Children), Prestasi Pustaka, Jakarta, 2012, p. 3 
and illegitimate children. It happens because the laws distinguish the legal effects of legitimate and illegitimate marriage or merely a relationship out of marriage. Marriage is a special contract of permanent union between a man and a woman entered into in accordance with law for the establishment of conjugal and family life. $^{2}$

In Indonesia, the provisions governing the relationship between husband and wife and the relationship between parents and children are included in Law No. 1 of 1974 on Marriage (UUP). Satjipto stated that the Marriage Law (UUP) is an interesting example of an attempt to obtain normative single condition for the entire country. ${ }^{3}$ In the Marriage Law (UUP) with its religious spirit, it does not expect the pattern of living together between men and women without legitimate marriage. Therefore, the children born are expected to be the product of a legitimate marriage under law. The Marriage Law (UUP) does not regulate the recognition and validation of illegitimate children so that the children born out of wedlock will forever be illegitimate children . Thus, according to the Marriage Law (UUP), the classification of children is identified only into legitimate and illegitimate children.

The Compilation of Islamic Law (KHI) as a guideline in deciding the cases in the religious courts, then, follows the provisions of the law as stipulated in article 99 (a) and Article 100.

The different things includedin the laws of colonial products which are still in force in Indonesia is the Indonesian Civil Code. The soul and philosophy of the Indonesian Civil Code are based on the ideology of freedom. With the ideology of freedom, including the relationship of men and women, it enables the living together between men and women without a legal marriage bond and without being concerned about the status of the children born from such a life. Hence, in the

\footnotetext{
${ }^{2}$ Alex L. Monteclar , 2011, An Overview of the Family Law of The Philippines, International Seminar Theme : Reccent Issues In Comarative Law, Semarang Indonesia, April $7^{\text {th }} 2011$.

${ }^{3}$ Satjipto Rahardjo, Pemanfaatan Ilmu Ilmu Sosial Bagi Pengembangan Ilmu Hukum (The Use of Social Sciences for the Development of Law Sciences), Genta Publishing (second edition), Yogyakarta, 2010, p. 114
} 
Indonesian Civil Code, it regulates the institution of the recognition and validation of illegitimate children so that the children born out of wedlock can be specified as illegitimate children, or even the legitimate ones.

To create a civil relationship between illegitimate children with their biological father, it needs to have the recognition initially in accordance with the procedures determined by law or made by a court decision. Oral recognition does not have any strength. In the recognition of illegitimate children, there is a relative relationship between the recognizing and recognized one. The legal effect between a child recognized by his/ her biological father who recognizes him/ her has the position similar to a legitimate child. Even, a child born out of wedlock can be recognized as a legitimate child. This happens when the child's parents, then, get married officially. It is a reality that, according the Indonesian Civil Code, the relationship of men and women without a legal marriage bond is justified by the law.

In the Marriage Law (UUP), the position of children born out of wedlock is just stipulated in the provisions of Article 43 paragraph (1) of Marriage Law (UUP) which states: a child born out of wedlock only has the civil relationship with his/ her mother and his/ her mother's family. The Marriage Law (UUP) only distinguishes legitimate and illegitimate children and does not regulate the institution of the recognition and validation of child. Consequently, when a child is born out of wedlock, the child is forever an illegitimate child.

The provision of Article 43 paragraph (1) of Marriage Law (UUP) was later amended by the Decision of the Constitutional Court No. 46/ PUU-VIII/ 2010, which states: "a child born out of wedlock only has a civil relationship with his/ her mother and his/ her mother's family". It should read, " a child born out of wedlock only has a civil relationship with his/ her mother and his/ her mother's family as well as with the man as a father who can be proved by science and technology and/ or other evidence according to the law to have blood relations, including the civil relation with his/ her father's family. " 
The Constitutional Court's decision becomes debatable and will be proven that this decision is difficult to implement in practice because the decision is in contrary with a variety of other legal systems, such as customary inheritance law, Islamic Inheritance Law, and the Inheritance Law of the Indonesian Civil Code. Thus, it is not only related to the substance of the pros and cons but also in its implementation.

Meanwhile, in Law No. 23 of 2006 on Population Administration, which was then amended to Law No. 24 of 2013, there is a provision governing the recognition and validation of a illegitimate children. The illegitimate children can be recognized according to Law No. 23 of 2006 are the illegitimate children in the narrow sense, whereas, according to Law No. 24 of 2013, the children who can be recognized are those who are born from an individual marriage (siri marriage).

The process of recognition in the two legislations is not through the process in court and there is no certainty for granted. However, the rule particularly only applies and is applied to those who are Christians. For those who are the adherers of Islam, it can not be implemented because Islam does not recognize the recognition and validation of children. The only way to protect the illegitimate children resulted from a sirri marriage is by applying for itsbat nikah to the Religious Courts. The appllication may not always be granted because it must meet the requirements specified by the Marriage Law (UUP) and the Islamic Law Compilation (KHI). Consequently, the Religious Courts do not grant every request of itsbat nikah. From the above description, the main issue is: why there are the rule diversities in the recognition of illegitimate children in Indonesia that causes legal disharmony.

\section{Research Methods}

The paradigm of the research used was the paradigm of constructivism or legal contructivism. In constructivism, reality can understood in the form of various mental construction and can not be sensed, based on social and experience, having local characteristic local and specific, and the shape and contents depend on the 
humans or groups of individuals who have the construction. ${ }^{4}$ Qualitative research method was used with the approach of Socio Legal. At this point, there were two aspects of the research; the aspect of legal research with the research objects in the form of law in the sense of "norm" and socio research which uses the methods and theories of social sciences concerning law to help the researcher perform the analysis.

\section{Result and Discussion}

After the publication of the Marriage law (UUP), all matters about marriage and related services shall be subject to the provisions of the Marriage Law (UUP). The Marriage Law manifested in the form of UUP, in accordance with the purposes of the law, seeks to accommodate the interests of society in an equitable and certainty norms ${ }^{5}$ All of the provisions set out in the Marriage Law (UUP) and the Implementation Regulation (the Government Regulation No. 9 of 1975) provide the assurance that such provisions have become effective. However, there is also a provision that has not been regulated in the Marriage Law (UUP), or it is set in the Marriage Law (UUP) but has not been regulated in the Government Regulation No. 9 of 1975. It means that the provision has not been effective. It regulates the position of children, the rights and obligations between parents and children, marital property, and guardianship.

For the ineffective provisions, in accordance with the provisions of Article 66 of Marriage Law (UUP), the old laws with their diversed rules can be applied, such as: Adat Law, Islamic Law, the Indonesian Civil Code, and so forth. The fact of plurality is used to describe a situation in which two or more systems of law apply side by side in a social field, to explain the existence of two or more systems

\footnotetext{
${ }^{4}$ Guba \& Lincoln, Berbagai Paradigma yang Bersaing dalam Penelitian Kualitatif (Various Paradigms Competing in Qualitative Research), in Norman K Denzin \& Yvonna S. Lincoln, (translator: Dariyatno dkk), Hand Book Of Qualitative Research, Pustaka Pelajar, Yogyakarta, 2009, p. 137

${ }^{5}$ Moediarti Trisnaningsih, Beberapa Persoalan Dalam Hukum Perkawinan di Indonesia (Some Issues in Indonesian Marriage Law), P3WSB, Bandung, 2009, p. 2.
} 
of social control prevailing in society, or to explain a situation in which two or more legal systems interact in a social life or a condition in which more than one legal system works side by side in activities and relationships within the community. ${ }^{6}$

Based on this provision, it means that illegitimate children still refer to the old laws since it does not have the regulation in the Government Regulation (PP) No. 9 of 1975 as the implementation regulations of the Marriage Law. Therefore, there were many cases of illegitimate children various backgrounds. It can be seen in the following cases below:

a. Illegitimate children as the result of a out of marriage relationship between a man and a woman who are both "native" of Indonesia and Muslims.

b. Illegitimate children as the results of a religious wedding (individual marriage/ siri marriage) between a man and a woman who are both the "native" of Indonesia and Muslims.

c. Illegitimate children as the results of out of marriage relationship between a man and a woman who are both the "native" of Indonesia and Christian or other than Muslims.

d. Illegitimate children religiously married (married in church) between a man and a woman who are both citizen "authentic" Christian or other than Islam.

e. Illegitimate children as the results of out of marriage relationship between a man and a woman who are both the "Chinsese descent"of Indonesia or the Indonesian citizen of European descent.

From the variety of cases, in order that illegitimate children get legal protection, a civil relationship with their biological fathers should be made, by conducting the recognition and validation of child. It should be understood that, in the state law, there is no difference between the illegitimate children as the results

\footnotetext{
6 I. Nyoman Nurjaya, Memahami Posisi dan Kapasitas Hukum Adat Dalam Politik Pembangunan Hukum Indonesia (Understanding the Position and Capacity of Adat Law in the Politic of Law Development in Indonesia), in Rachmad Syafa'at et al, Negara, Masyarakat Adat dan Kearifan Lokal (State, Customary Community, and Local Wisdom), in-TRANS Publishing, Malang, 2008, p. 50-51.
} 
of illegal relationship and the illegitimate children from religious marriage (sirri marriage or married in the church only). They are both still considered as illegitimate children. It can be shown that in the child's birth certificate, both from out of marriage relationship and sirri marriage, it only registers the name of the mother without the biological father's name. Consequently, the child is, in the state law, is an illegitimate child.

When the recognition or validation of illegitimate children will be conducted, as in the five cases above, it will contradict with some related instruments governing the position of illegitimate children as well as the recognition and validation of illegitimate children, as follows:

\section{a. Law No. 1 of 1974 on Marriage (UUP):}

Under the provisions of the Marriage Law (UUP), there is no space for illegitimate children to have civil relationship with their biological fathers. It is as stated in Article 43 paragraph (1) of the Marriage Law (UUP) that a child born out of wedlock only has the civil relationship with his/ her mother and his/ her mother's family. In addition, the Marriage Law (UUP) does not recognize the recognition and validation of illegitimate children. As a result, the children born out of wedlock will forever have the position as illegitimate children.

In other hand, there is actually no protection to the "candidate" of illegitimate childre in the Marriage Law (UUP) in another form, namely, to the woman who is pregnant out of marriage that she may be married to a man who is not the biological father of the child in the woman's womb. It is solely to protect in order that the child born remains a legitimate child. The child will have a birth certificate with the name of his/ her mother and the man who marry the mother. It means that the child is legally legitimate. According the Marriage Law (UUP), a legitimate child is a child born or as a result of a legal marriage. Thus, the father of a legally legitimate child is not always his/ her biological father.

After the issuance of the Constitutional Court Decision No. 46/ PUU-VIII/ 2010, an illegitimate child may have a civil relationship with his/ her biological 
father by applying to the court to be scientifically proven by a DNA test. In other words, it has to go through the process of evidence in a trial. However, when the petition is granted, the illegitimate child's position is still unclear whether he/ she is the same as a legitimate child, or he/ she is a recognized illegitimate children. The conclusion of the Constitutional Court Decision is difficult to implement in practice because it conflicts with the other legal systems, such as the inheritance laws that apply in Indonesia; customary inheritance law, Islamic law, and the inheritance law of the Indonesian Civil Code.

\section{b. Compilation of Islamic Law (KHI)}

When referring to the provisions of the Compilation of Islamic Law (KHI), there are opportunities to create a civil relationship with the biological father, in the form of itsbat nikah. In itsbat nikah (marriage legalization), through a petition to the Religious Courts to the marriage that has been held in religion (sirri marriage). This method should also be conducted through the process of trial. Then, the Compilation of Islamic Law (KHI) provides the protection in the limited form because not all the petition of itsbat nikah can be granted. When the itsbat nikah is granted, automatically a child who has been born from a siri marriage is a legitimate child.

\section{c. According to the Indonesian Civil Code}

In the Indonesian Civil Code, a legal instrument in the form of the recognition and validation of children is provided to protect illegitimate children. When the recognition of the child is performed by his/ her biological father with the approval of his/ her mother, the position of the illegitimate child is a recognized illegitimate child. Even if the parents are later married officially, automatically the recognized illegitimate child turns into a legitimate child. 


\section{d. Under Law No. 23 of 2006}

According to Law No. 23 of 2006, illegitimate children may get the recognition and validation of child in certain conditions, particularly for Indonesian Christian groups. In this law, the illegitimate children who can be recognized are not the illegitimate children of individual marriages. Thus, Law No. 23 of 2006 still gives the broad meaning in the recognition of illegitimate children. It is similar to or the adoption of the institution of recognition in the Indonesian Civil Code.

\section{e. Under Law No. 24 of 2013}

According to Law No. 24 of 2013, the illegitimate children of religious marriages (Christianity) may get the recognition and validation of child in certain conditions, particularly for the Indonesian Christian groups. In Law No. 24 of 2013 which is the amendment to Law No. 23 of 2006, there is a crucial change to recognized illegitimate children, who initially were "illegitimate children" (without the bond of a religious marriage), to be limited only as the illegitimate children of religious marriages.

Referring to the various provisions governing the position of illegitimate children or the ones governing the recognition and validation of illegitimate children, they show the distinctions between the ones and the others. It is unclear; which regulations should be applied when dealing with the recognition or vallidation of illegitimate children. Illegitimate children of religious marriages (individual marriage/ siri marriage) between a man and a woman who are both the "native" of Indonesia and Muslims will have trouble (incapable) when they will perform the recognition and validation through Law No. 23 of 2006 or Law No. 24 of 20013. For example, an illegitimate child from an out of marriage relationship between a man and a woman who are both the "Chinese descent" of Indonesia who should be able to conduct the recognition and validation of illegitimate children by the Indonesian Civil Code has unclear legal provision when using the provisions of Law No. 23 of 2006 and Law No. 24 of 20013. 
Based on the description above, it can be questioned; which law applies in the recognition and validation of illegitimate children recently. If the provisions of the Indonesian Civil Code still apply as they do to the laws of inheritance and marital property, those who are subject to the Indonesian Civil Code, such as the Indonesian Chinese Descendants, the provisions on the recognition and validation of illegitimate children are also still valid. The next issue is: whom does Law No. 23 of 2006 in conjunction with Law No. 24 of 2013 apply for? In fact, the research results of the provisions of the recognition and validation of illegitimate children in the law are applied to the Indonesian Christians and Indonesian Chinese. Similarly; whom shall the provision of Article 43 paragraph (1) of the Marriage Law (UUP) which was amended by The Constitutional Court Decision No. MK 46/ PUU-VIII/ 2010 apply to?

Thus, in Indonesia, there is no uniformity in the effort to protect illegitimate children to obtain their civil rights with their biological fathers. There is a plurality of rules in which between a rule and the other one overlaps, which leads to legal uncertainty and inequality in the recognition and validation of illegitimate children.

Besides, there is also no uniformity in the object of recognition causing the obscurity on which illegitimate children who can be recognized and validated. According to the Indonesian Civil Code, the illegitimate children who can be recognized are the illegitimate children in the narrow sense excluding illicit and incestuous children. Under the provisions of the Marriage Law (UUP) after the decision of the Constitutional Court No.46/ PUU-VIII/ 2010, it still causes multiple interpretations for the illegitimate children who can claim their civil relationship with their biological fathers. On the other hand, according to Law No. 23 of 2006, the illegitimate children who can be recognized is the same as those in the Indonesian Civil Code. According to the Law No. 24 of 2013, the illegitimate children who can be recognized are the illegitimate children from siri marriage. Similarly, in the practice of itsbat nikah, the illegitimate children who can be validated are the illegitimate children from siri marriage. 
From the study of the practice of organizing the recognition and validation of illegitimate children or the attempt to give legal protection to illegitimate children that had occurred in Indonesia, there are various ways and forms due to the diversity of the rules. It can cause legal disharmony or confusion. Legal harmonization is developed in the science of law that is used to indicate that in the world of law, the government policies and their relationships have the diversity that can lead to disharmony. ${ }^{7}$ The following is an overview of the implementation of the recognition of illegitimate children and the legal effect.

\section{Table 1: The Model of the Recognition of Validation of Illegitimate Children in Various Rules}

\begin{tabular}{|c|c|c|c|c|}
\hline Legal Basis & $\begin{array}{l}\text { Illegitimate } \\
\text { Children } \\
\text { (ALK) }\end{array}$ & Procedures & Legal Effect & Remark \\
\hline $\begin{array}{l}\text { The } \\
\text { Marriage } \\
\text { Law in } \\
\text { conjunction } \\
\text { with the } \\
\text { Constitutiona } \\
1 \text { Court } \\
\text { Decision No. } \\
\text { 46/ PUU- } \\
\text { VIII/ } 2010\end{array}$ & $\begin{array}{l}\text { ALK and } \\
\text { ALK from } \\
\text { siri marriage }\end{array}$ & $\begin{array}{l}\text { Applying the lawsuit to } \\
\text { the District Court }\end{array}$ & $\begin{array}{l}\text { There is no } \\
\text { clarity due to } \\
\text { the law of the } \\
\text { civil rights of } \\
\text { illegitimate } \\
\text { children }\end{array}$ & $\begin{array}{l}\text { - Must be through } \\
\text { judicial process. } \\
\text { - difficult in its } \\
\text { implementation }\end{array}$ \\
\hline $\begin{array}{l}\text { Law No. } 23 \\
\text { of } 2006\end{array}$ & ALK & $\begin{array}{l}\text { - The biological father } \\
\text { recognizes with the } \\
\text { consent of the child's }\end{array}$ & $\begin{array}{l}\text { There is no } \\
\text { clarity on the } \\
\text { legal effect of }\end{array}$ & $\begin{array}{l}\text { Without judicial } \\
\text { process }\end{array}$ \\
\hline
\end{tabular}

${ }^{7}$ Kusnu Goesniadhi, Harmonisasi Hukum : Dalam perspektif undang undang (Harmonization of Law: in the Perspective of Law). JP BOOKS, Surabaya, 2006, p. 62-63 


\begin{tabular}{|c|c|c|c|c|}
\hline & & $\begin{array}{l}\text { mother. } \\
\text { - Submitting an } \\
\text { application for the } \\
\text { recognition record in } \\
\text { KCS. }\end{array}$ & $\begin{array}{l}\text { the civil rights } \\
\text { to ALK }\end{array}$ & \\
\hline $\begin{array}{l}\text { Law No. } 24 \\
\text { of } 2013\end{array}$ & $\begin{array}{l}\text { ALK of siri } \\
\text { marriage }\end{array}$ & $\begin{array}{l}\text { - There is evidence of a } \\
\text { religious marriage } \\
\text { (church) before. } \\
\text { - The biological father } \\
\text { recognizes with the } \\
\text { consent of the child's } \\
\text { mother. } \\
\text { - Submitting an } \\
\text { application for the } \\
\text { recognition record in } \\
\text { KCS. }\end{array}$ & $\begin{array}{l}\text { There is no } \\
\text { clarity on the } \\
\text { legal effect of } \\
\text { the civil rights } \\
\text { to ALK }\end{array}$ & $\begin{array}{l}\text { Without judicial } \\
\text { process }\end{array}$ \\
\hline $\begin{array}{l}\text { Islamic Law } \\
\text { Compilation( } \\
\text { KHI) }\end{array}$ & $\begin{array}{l}\text { ALK of siri } \\
\text { marriage }\end{array}$ & $\begin{array}{l}\text { Applying itsbat nikah to } \\
\text { the Religious Court }\end{array}$ & $\begin{array}{l}\text { Becoming } \\
\text { legitimate } \\
\text { children }\end{array}$ & $\begin{array}{l}\text { - does not } \\
\text { recognize child } \\
\text { recognition. } \\
\text { - Through judicial } \\
\text { process } \\
\text { - Itsbat is not } \\
\text { always granted. }\end{array}$ \\
\hline $\begin{array}{l}\text { The } \\
\text { Indonesian } \\
\text { Civil Code }\end{array}$ & ALK & $\begin{array}{l}\text { - The biological father } \\
\text { recognizes with the } \\
\text { consent of the child's } \\
\text { mother. } \\
\text { - the recognition is made } \\
\text { by making the note at the }\end{array}$ & $\begin{array}{l}\text { - Becoming the } \\
\text { recognized } \\
\text { illegitimate } \\
\text { children. } \\
\text { - having the } \\
\text { clear and }\end{array}$ & $\begin{array}{l}\text { Without judicial } \\
\text { process }\end{array}$ \\
\hline
\end{tabular}




\begin{tabular}{|l|l|l|l|}
\hline & $\begin{array}{l}\text { edge of the child's birth } \\
\text { certificate, with an } \\
\text { authentic certificate, in } \\
\text { the marriage certificate, } \\
\text { and with the certificate } \\
\text { made by the officer of the } \\
\text { civil registration }\end{array}$ & relationship. & \\
\hline
\end{tabular}

Referring to the implementation of the recognition and validation to illegitimate children, it indicated a sharp distinction between the illegitimate children whose parents are Muslims and non-Muslims, particularly Christians. For those who are Muslims, they had to go through the judicial process by filing a request of itsbat nikah first, while, for the Christians, they arranged for it without a judicial process and could apply for the recognition of the child with the certainty to be granted. In other hand, the applications of itsbat nikah were not always granted by the court because it had to meet the strict requirements specified in the Islamic Law Compilation (KHI). When it is refused, it means that the child will forever be an illegitimate child. Hence, there is no guarantee that the illegitimate children from siri marriage carrierd out according to Islam can get legal protection. It can be said that there has been a discrimination and injustice in the administration of the recognition of illegitimate children in Indonesia.

From a variety of conditions governing the legal protection to illegitimate children, it is certainly called into question by the existence of the Constitutional Court Decision No. 46/ PUU-VIII/ 2010. On the one hand, it can be seen as a decision with the paradigm of progressive law. Progressive law is a legal paradigm that grows and develops in the setting of Indonesia. The paradigm of progressive law is more oriented to substantial justice because the goal is to form a legal system 
in favor of justice and the welfare of the people as much as possible, and make people happy. ${ }^{8}$

For those who are subject to the Indonesian Civil Code, it can be said the Constitutional Court Decision does not affect anything since the Indonesian Civil Code has already regulated the status of children in detail, including illegitimate children.The form of legal protection to illegitimate children by the Indonesian Civil Code is conducted by the recognition to them so that the children has the position as recognized illegitimate children and, the legal effect, they have civil rights to their biological fathers who recognize them. This is analogous to the decision of the Constitutional Court. In addition, illegitimate children can also be legitimate children when they are recognized and their parents carry out a marriage. In this case, it means that a child who is initially born out of wedlock change his/ her position into a legitimate child. Perhaps, if the decision of the Constitutional Court is applied to those who are subject to the Indonesian Civil Code, it will raise the issue of the position of illicit children who, according to the Indonesian Civil Code, can not be recognized. However, the Constitutional Court Decision can give them the civil relationship with their biological father.

Similarly, the Constitutional Court Decision does not affect the provisions of Law No. 23 of 2006 in conjunction with Law No. 24 of 2013 on Population Administration which more or less adopts the institution of the recognition and validation of illegitimate children from the Indonesian Civil Code. Without referring to the decision of the Constitutional Court, the Office of Population and Civil Registration has organized the recognition and validation for illegitimate children. Under Law No. 23 of 2006 and Law No. 24 of 2013, illegitimate children can be legitimate children with the conditon that the recognition and validation havee been carried out first. Nevertheless, the reality of this provision is only for the Indonesia Christian groups.

\footnotetext{
${ }^{8}$ Satjipto Rahardjo, Hukum Progresif : Sebuah sintesa hukum Indonesia (Progressive Law: A Synthesis of Indonesian Law), Genta Publishing, Yogyakarta, 2009, p. 5-6.
} 
It can be found in the practices of the recognition and validation of children organized by the Office of Population and Civil Registration (KCS) below ${ }^{9}$

Table 2 : The Recognition and Validation of Illegitimate Children

\begin{tabular}{|c|c|c|c|}
\hline Year & KCS Semarang & KCS Bandung & KCSYogyakarta \\
\hline 2013 & $56-55$ & $67-177$ & 0 \\
\hline 2014 & $59-59$ & $3-149$ & 0 \\
\hline 2015 & $43-43$ & $0-192$ & 0 \\
\hline
\end{tabular}

The implementation of the recognition and validation of illegitimate children at the Office of Population and Civil Registration (KCS) Semarang is based on the provisions of Law No. 23 of 2006 in conjunction with Law No. 24, 2013. Normally the recognition of children is followed by validation so that the table does not show the synchronization between the recognition and validation of children.

The prerequisite for the recognition is the evidence of marriage that has been performed according to the religious law in advance (in the church). It makes it clear that only the children born from individual marriage (siri marriage) who can be recognized or validated. The illegitimate children born not from siri marriage are not protected by law because they can not be recognized or validated.

In addition, KCS Semarang also did not serve the recognition and validation of illegitimate children from Muslim parents. It is associated with the provisions of the law which states: "The obligation to report on the recognition of the child is not allowed for the parents who, in their religion regulation, do not justify the recognition of children born from a legal marriage bond". Apparently, KCS Semarang had drawn the conclusion that the provision which states "that the regulation prohibits the recognition and validation of illegitimate children" is for

9 Thte research results at KCS Semarang, KCS Bandung, and KCS Yogyakarta (July-August 2016). 
Muslim. It was also corroborated in previous practices that there has never been a recognition and validation of child from Muslim parents.

In the implementation of the recognition and validation of illegitimate children by the Office of Population and Civil Registration in Bandung, formally, there are different treatments among the community groups in Indonesia. The law does not distinguish whether the child's recognition and validation is from Muslims or non-Muslims. The provisions only state if the religion prohibits it or not. KCS Bandung, there has never been the practice of the recognition and validation of children from Islamic groups because there must be an evidence of a religious marriage (an evidence of marriage from the church for Christianity).

Why in every Office of Population and Civil Registry there was no recognition and validation of illegitimate from Muslim parents although by law it is possible. The cause is that the requirement to apply for the recognition and validation of illegitimate children must be with written proof (the registration by the religious leaders) stating that there has been a marriage in a religious way. This is the one that can not be met by the Islamic community since a religious marriage/ siri marriage never have any written evidence. Besides, the Islamic Law Compilation (KHI) does not regulate the recognition and validation of illegitimate children.

Similarly, in KCS Yogyakarta, there has never been a recognition and validation of illegitimate children. It is related to the policy in the KCS that: the recognition and validation of children shall be with the evidence of religious marriage (but the marriages were held before October 1975). The policy minimized the rampant abuse of siri marriage.

Thus, until today, there is no definite provision with unification in nature for the administration of the recognition of illegitimate children and for realizing the rights attached to the illegitimate children. 


\section{Conclusion}

The confusion (disharmony of law) in the regulation of the recognition and validation of illegitimate children showed the presence of various legal systems governing the recognition and validation of illegitimate children, and they were not synchronized with each other and overlapped. It resulted in the absence of similarity of treatment in the implementation of the recognition and validation practices of illegitimate children, and there were the discriminations that led to injustice and legal uncertainty. It was caused by the Marriage Law (UUP) as the legal umbrella which does not regulate the position of illegitimate children in the Government Regulation (PP No. 9 of 1975) as promised by the Marriage Law (UUP). As a result, various rules on the recognition and validation of ilegitimate children appeared and overlapped, either in relation to illegitimate children as the object of recognition and validation or the recognition procedures and the legal effect of the recognition and validation.

\section{References}

Anshary MK, H.M., (2010).Hukum Perkawinan Indonesia : Masalah- masalah krusial. Yogyakarta : Pustaka Pelajar.

Ginsberg, Morris. (2003).Keadilan dalam Masyarakat. Yogyakarta : Pustaka Yogya Mandiri.

Kusnu, Goesniadhi. (2006).Harmonisasi Hukum : Dalam perspektif undang undang. Surabaya : JP BOOKS.

Guba \& Lincoln. (2009), Berbagai Paradigma yang Bersaing dalam Penelitian Kualitatif, dalam Norman K Denzin \& Yvonna S. Lincoln, (penerjemah: Dariyatno dkk), Hand Book Of Qualitative Research. Yogyakarta : Pustaka Pelajar.

Kusuma, Mahmud. (2009). Menyelami Semangat Hukum Progresif. Yogyakarta : antonyLib \& LSHP Indonesia.

Lebacqz, Karen. (2011).Teori Teori Keadilan, terjemahan oleh Yudi Santoso. Bandung : Nusa Media.

Monteclar, Alex L. (2011). An Overview of the Family Law of The Philippines, International Seminar Theme : Reccent Issues In Comarative Law. Semarang Indonesia, April $7^{\text {th }} 2011$. 
Menski, Werner. (2006). Comparative Law in Global Context, The Legal System of Asia and Africa. Second Edition, United Kingdom : Cambridge University Press.

Mudzakkir, Amin. (2010).Ketika Hukum Menciderai Keadilan.Kompas Opini 28 Desember 2010.

Nurjaya, I. Nyoman. (2008).Memahami Posisi dan Kapasitas Hukum Adat Dalam Politik Pembangunan Hukum Indonesia, Dalam Rachmad Syafa'at dkk, Negara, Masyarakat Adat dan Kearifan Lokal. Malang :in-TRANS Publishing.

Purba, Rehngena. (2012).Hukum Acara Pengukuhan Anak Luar Kawin Sebelum dan Pasca Putusan Mahkamah Konstitusi, Makalah, disampaikan dalam Seminar dan diskusi ilmiah anak luar kawin, diselenggarakan oleh SS.co ADVOCATES, Jakarta, 29 Maret 2012.

Rahardjo, Satjipto. (2009).Hukum Progresif : Sebuah Sintesa Hukum Indonesia. Yogyakarta : Genta Publishing.

---Pemanfaatan Ilmu Ilmu Sosial Bagi Pengembangan Ilmu Hukum. Yogyakarta :Genta Publishing.

Tan Thong Kie. (2007).Studi Notariat \& Serba Serbi Praktik Notaris. Jakarta: PT Ichtiar Baru Van Hoeve.

Moerdiati, Trisnaningsih. (2009).Beberapa Persoalan Dalam Hukum Perkawinan di Indonesia. Bandung : P3WSB.

Witanto, D.Y. (2012).Hukum Keluarga : Hak dan kedudukan anak luar kawin. Jakarta : Prestasi Pustaka. 